\title{
Multi Selection Control Algorithm in Examination Invigilation Management System (ExIMS) for Exchanging Invigilation Duties Among Invigilators at UiTM Pulau Pinang Branch
}

\author{
Jamal Othman ${ }^{1 *}$, Sharifah Sarimah Syed Abdullah ${ }^{2}$, Norshuhada Samsudin ${ }^{3}$, \\ Wan Nur Shaziayani ${ }^{4}$ \\ ${ }_{1,2,3,4}$ Department of Computer and Mathematical Sciences, \\ Universiti Teknologi MARA, Pulau Pinang Branch, Permatang Pauh Campus, \\ 13500 Permatang Pauh, Pulau Pinang \\ Corresponding author: *jamalothman@uitm.edu.my \\ Received Date: 30 December 2020 \\ Accepted Date: 27 January 2021 \\ Published Date: 14 March 2021
}

\section{HIGHLIGHTS}

- Preparation of invigilation duties requires a lot of concentration and full of patience.

- Multi Selection Control Algorithm has been constructed to verify the invigilation duties exchanged among the invigilators.

- A survey using the TAM methods has been applied to measure users' satisfaction on invigilation duties exchanged.

\begin{abstract}
Invigilation of the examination is one of the important roles and tasks of lecturers appointed as invigilators or proctors. Based on the past semi-annually reports of examination post-mortems meeting, less than 10\% of the invigilators were unhappy with the examination duties that have been assigned or appointed to them. The examination committee members who are responsible in the process of assigning the invigilation duties to each invigilator had given a lot of effort and spent a few weeks to ensure that everybody is happy with the invigilation duties assigned to them. Nevertheless, despite the excellent planning of invigilation duties assignment, it cannot make everybody satisfied. Thus, a web-based application system named Examination Invigilation Management Systems (ExIMS) has been developed using the System Development Life Cycle (SDLC) waterfall model methodology to meet the need of invigilation duties exchanged among invigilators or applicants. This system has been developed to control and cross check the request of invigilation duties exchanged using the algorithm named multi selection control. The algorithm could avoid any conflicts or anomalies that could happen after the exchange of duty has been made. The process of duty exchange is examined and verified automatically by the system. The system provides a platform for users or invigilators to give their views or opinions on the invigilation duties and system features or performance through the online survey. The survey uses the TAM method concentrating on the perceived-ease-of-use (PEOU) component. Based on the survey, 95\% respondents reported that they were satisfied with the platform for duty exchange among invigilators. The users can easily and flexibly select the new duties, which will be automatically and mutually swapped among invigilators. ExIMS has solved the problem of unsatisfaction of invigilation duties and increased the happiness index among invigilators during the examination period.
\end{abstract}

Keywords: invigilation, ExIMS , SDLC, multi selection, TAM

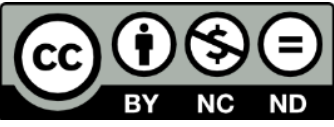




\section{INTRODUCTION}

Examination management is the most important operation besides records and administration at Academic Affairs Department of any education institutions. Examination operation can be detailed up into several sub operations such as preparation of examination questions, printing and packaging of question papers, preparation of examination schedules and venues, preparation of invigilation duties among invigilators or proctors, whereas the final sub operation is the marks processing management (Quality, 2010; UiTM, 2016).

As stated in The Values and Ethics of UiTM Lecturers book (UiTM, 2001), examination operation needs the role and support of the lecturers to invigilate the examination. The invigilation duties among lecturers are prepared through a system called the Examination Management System (EMS) and improvised wisely and professionally by the examination committee before the schedules are released to the invigilators (Othman et al., 2018). Nevertheless, based on the past reports of examination post-mortems meeting and verbal feedbacks from the invigilators, approximately $8 \%$ of appointed invigilators were unhappy with the examination duties or schedules assigned to them (HEA, 2019). Among the feedbacks or noticeable reasons were that the schedules did not consider the time when they were busy with marking the final examination papers and reading the students' reports. Other reasons include invigilating during weekend slots, invigilating the 3-hour examination instead of 2-hour examination, appointed as chief invigilator that requires a lot of tasks and responsibilities to be managed by the lecturers or invigilators, as well as invigilating at bigger venues such as the big examination halls which requires a lot of checking, reporting and walking, consequently making them very tired after the invigilation. The study on invigilation duties at Universiti Malaysia Pahang (UMP) demonstrated that the invigilators were also facing a problem whereby the invigilation duties assigned to them never consider the gaps between one invigilation duty to the next duty (Mat Yusof, 2018). The invigilation duties assigned to them were back-to-back.

Other conditions that require the invigilators to find someone else for invigilation replacement in urgent situations such as the invigilators had a sudden meeting that was more important than the invigilation duties, emergency cases such as being unhealthy or not fit to perform the invigilation duty, unplanned situation like family death news, car breakdown and other unexpected incidents. Therefore, it is highly recommended that a comprehensive platform is provided to centralise and consolidate all requests of invigilation duties exchange among invigilators. From there, the exchange of invigilation duties can be made easily anywhere and anytime with hustle free.

The objective of this paper is to develop a web-based application and provide one stop centre or a platform for all invigilators to check their respective examination schedules and allow them to easily make the invigilation duty exchange if required. Currently, the invigilators need to fill-in a form and submit it to the Examination Officer at Examination Unit of Academic Affairs Department for approval. The exchange of invigilation need to be done manually by the invigilators whereby they must find and make sure the substitute invigilator agreed to exchange the task. If none of the invigilators agreed to exchange the invigilation, the original invigilation will be retained until there is a volunteer willing to replace. The main feature of the new system is that the invigilation of the invigilators who requested for exchange will be partially released on the web until the substitute invigilator has confirmed or willing to replace the invigilation. Once the invigilation is selected, the invigilator needs to select any available invigilation tasks released by other invigilators for replacement of the original invigilation. The scope of this project is narrowed to prime examination only. The supplementary or intersession examinations are excluded. Additionally, the requests for invigilation exchange is not limited to the academic staff only, but also expands to administration staff appointed as invigilators.

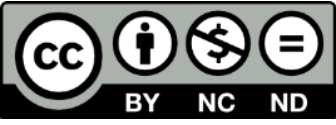

Copyright $\odot 2021$ UiTM Press. This is an open access article under the CC BY-NC-ND (https://creativecommons.org/licenses/by-nc-nd/4.0/) 
The organisation of this paper is first done by introducing the main purpose, objectives and scopes of this project. The related research or project using varieties of techniques and features applied in the systems are also briefly discussed. The following section further explains the algorithm applied in the Examination Invigilation Management Systems (ExIMS) called Multi Selection Control. The methodology applied for this project is the System Development Life Cycle (SDLC), which compliments with web-based application development. To measure the invigilators' satisfaction level, the online survey using the Technology Acceptance Model (TAM) as an instrument for evaluation purposes was conducted to measure the system effectiveness. Finally, overall research findings and future improvement are presented in the final section.

\section{LITERATURE REVIEW}

The university timetabling system involves the class scheduling and final examination timetable scheduling that requires the data of subjects, rooms, lecturers and tutors, students and administrative staff allocated to the specific date and time (Gaspero et al., 2003). Preparation of examination schedules especially at tertiary education involves a lot of unstructured or complex constraints that need to be specified either soft or hard constraints (Carter \& Laporte, 1997). Generally, the examination scheduling system initiated and innovated by some experts have introduced a few techniques such as mathematical modelling (Sagir \& Ozturk, 2010), constructive heuristic approach (Kahar \& Kendall, 2010), particle swarm based hyper-heuristic approach (Ahmed et al., 2011), bender's partitioning (Sarin, Wang \& Varadarajan, 2010) and graph colouring framework (Mohamed, Mushi \& Mujuni, 2013).

Lexis Examination Invigilation System has been developed at Imperial College in London (Wyer \& Eisenbach, 2001). The invigilation of the examination does not use the human energy, but is controlled by the system installed on the computer. This kind of system is normally applicable if the students are required to conduct online assessment like the programming course. The students must use the computer in the laboratory. Simple questions that require the students to write the codes within the allotted time will be sent via email to students. The students have no access to the Internet and the resources for their references during the online test are very limited or only permitted to authorised folder. This situation of examination does not require many invigilators and practically only one invigilator to observe technical operation of the system.

Exam Cell Automation Systems has been initiated and implemented at the Department of Computer Science Engineering in India (Dharshini \& Sudha, 2018). The main objective of this system is to simplify the process of assigning the examination venues and invigilation duties among proctors. The technique used for invigilation duties assignment is by using the excel spreadsheet. Once the assigning process is done, the data are uploaded to the database of the system. However, the request for invigilation duty exchange among proctors need to be done manually because the system does not provide a special platform for duty exchange.

Simple sequential assignment algorithm for invigilation examination duties has been developed and implemented at UiTM Pulau Pinang branch (Othman et al., 2017). This algorithm is constructed using Java programming language to generate the invigilation duties for almost 400 invigilators or proctors within less than five seconds. This powerful algorithm is applied during the first cycle of processing of invigilation duties. The invigilation duties processed in the first cycle will be scrutinised and improvised manually by the examination committee before being released to all invigilators. Similar to the Exam Cell Automation System, the application for invigilation duty exchange must get approval from the examination officer.

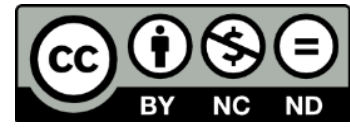

Copyright $\odot 2021$ UiTM Press. This is an open access article under the CC BY-NC-ND (https://creativecommons.org/licenses/by-nc-nd/4.0/) 
An Automated Examination Support Systems at University of Mumbai, India, is a comprehensive examination system that consolidates all major examination functions such as the examination schedule, examination placement, invigilation module and examination marks processing management (Avinash et. al, 2015). The newly examination system allows the invigilators to view respective invigilation duties and make the duty exchange. The system examines the conditions for duty exchange such as not invigilating the subject taught, not clashing with other invigilation duties, each invigilation duty should have at least 2 days gap and the invigilator is appointed with appropriate role that has been decided and set in the system either as the chief or assistant invigilator. This feature allows the invigilators to perform duty exchange easily, thus promoting the cultivation of positive values among invigilators by following certain standard of examination operating procedure (SOP) with full trustworthiness.

\section{METHODOLOGY}

System Development Life Cycle (SDLC) methodology was applied for the overall process of project development. SDLC is the common methodology practiced by most of ICT experts or practitioners in the system development. The SDLC methodology consists of various models such as the Waterfall, Spiral, Iterative, V-shaped and Agile (Existek, 2020). This project embedded the waterfall model, which compliments or suits for web-based application development. The following Figure 1 shows the stages of SDLC waterfall model as introduced by Dr Winston in 1970 (Winston, 1970).

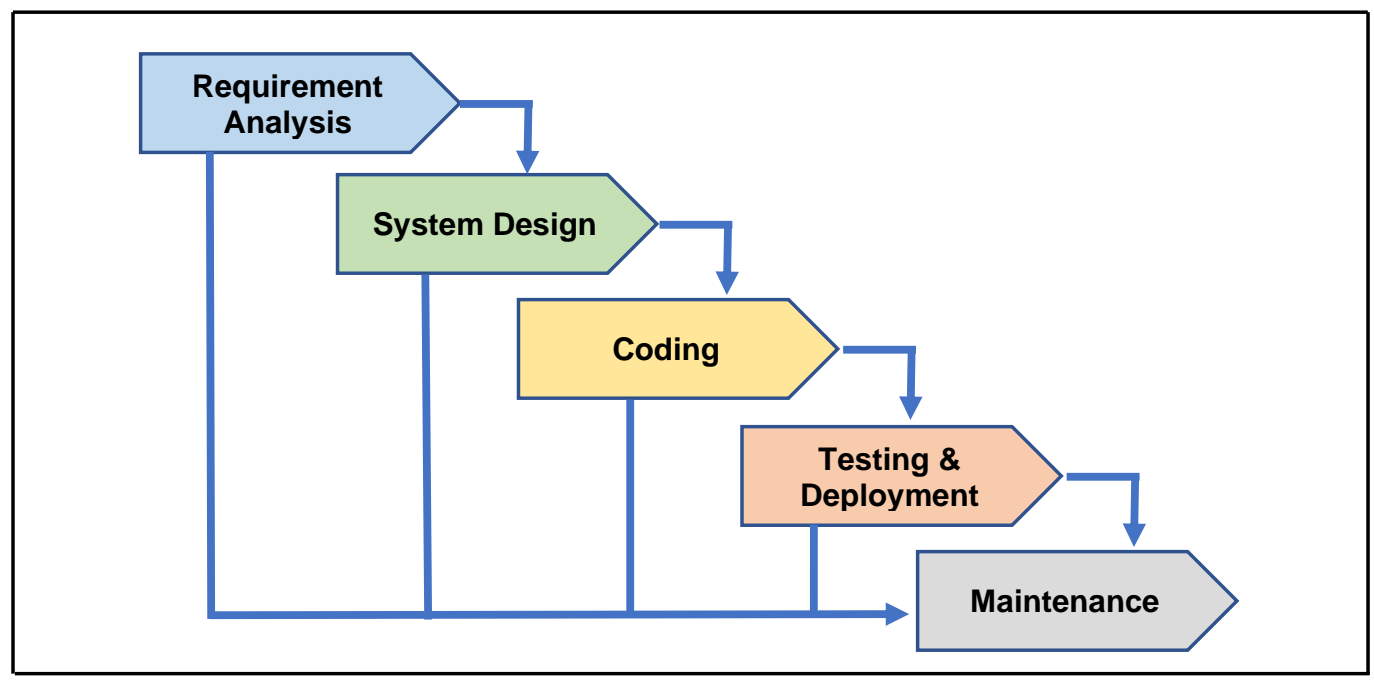

Figure 1: System Development Life Cycle, Waterfall models

Requirement Analysis is the first stage of SDLC waterfall model. During this stage, the system developer will have a series of meeting or interviews with the stakeholders or users leading to discussion on system requirements. The users and developers must clearly define the problem statements, objectives and scopes of the project before scrutinising the functional and nonfunctional requirements of the system. During this stage, the developers must review and observe all information that have been gathered from the stakeholders to ensure validity, precision, legality and the most important element is the ability to avoid any ambiguity and anomalies. Once the information gathered during the first stage are well documented, validated and verified, the next stage is the System Design. The stage requires the developer to translate the abstract of the information gathered during the requirement analysis into architectural design. During this stage, the discussion is much more on the technical aspects in which the developer will design the physical scheme

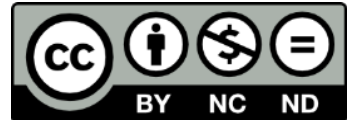

Copyright $\odot 2021$ UiTM Press. This is an open access article under the CC BY-NC-ND (https://creativecommons.org/licenses/by-nc-nd/4.0/) 
of database, the screen design for system menus, input screen and the standards of system reporting. In addition, the developer team will consider the system security and network architectural design besides the discussion of managerial aspects such the budget, project duration, manpower and technological constraints during the project development. The system design documentations must align with the user requirements and mutually agreed by the stakeholders before proceeding to coding stage.

The coding or implementation stage is the actual development. Programmers will start to translate the system design documentation into writing the source code. The programmers must consider that the written source code should be aligned with the requirements defined during the first stage. The source code will be compiled to avoid errors or bugs in the system. Programmers must identify all possible errors that could happen. In the coding and testing stage, both can be performed simultaneously. In practice, the users will be asked to test the system functionality as soon as the development of system submodules are completed in all stages. Once the testing has been done thoroughly by the users and developers, the system will be deployed at the users' site with continuous testing until it runs well and smoothly. After the deployment of the system, the system will be observed for 6 months and if any system becomes malfunction, further action will be taken immediately without delay.

The final stage of SDLC water model is the maintenance. The systems maintenance is parallel while the system is running. The main purpose of system maintenance is to handle or be prepared with unexpected system malfunctions, enhance and improvise the system based on the current technology demands and strengthen the system security. All the five stages of SDLC waterfall models are vital to ensure that the system is developed within the estimated time and allocated budget, while the ultimate mission is for the system to be successfully implemented without failures.

During the coding stage, a special algorithm called multi selection control technique will be applied for invigilators who requested for invigilation duty exchange. The developers had series of meeting and interviews with the users during the first stage of SDLC to confirm the constraint or condition lists for the system to verify and accept the invigilation duty exchange. The following Table 1 shows the list of constraints or conditions that need to be considered and fulfilled by the system whenever the invigilators request for invigilation duty exchange.

Table 1: List of constraints or conditions

\begin{tabular}{|c|c|}
\hline $\begin{array}{l}\text { Constraint } \\
\text { number }\end{array}$ & Constraint or condition description \\
\hline C1 & $\begin{array}{l}\text { Selected invigilation does not clash with any invigilation of the same } \\
\text { invigilator. }\end{array}$ \\
\hline $\mathbf{C 2}$ & $\begin{array}{l}\text { Selected invigilation is not the invigilation that had already passed over the } \\
\text { current date. }\end{array}$ \\
\hline C3 & $\begin{array}{l}\text { Selected invigilation will be rejected if the invigilator is not entitled as chief } \\
\text { invigilator. }\end{array}$ \\
\hline C4 & $\begin{array}{l}\text { Selected invigilation will be rejected once the invigilation task has been } \\
\text { chosen earlier by another invigilator. }\end{array}$ \\
\hline
\end{tabular}

The constraints $\mathrm{C} 1$ until $\mathrm{C} 4$ are classified as hard constraints that must be constructed in the system algorithms. Otherwise, the system is considered overruling the standard of examination operating procedure. The following Figure 2 shows the basic algorithm structure named multi selection control for invigilation duty exchange.

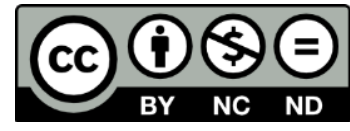

Copyright $\odot 2021$ UiTM Press. This is an open access article under the CC BY-NC-ND (https://creativecommons.org/licenses/by-nc-nd/4.0/) 


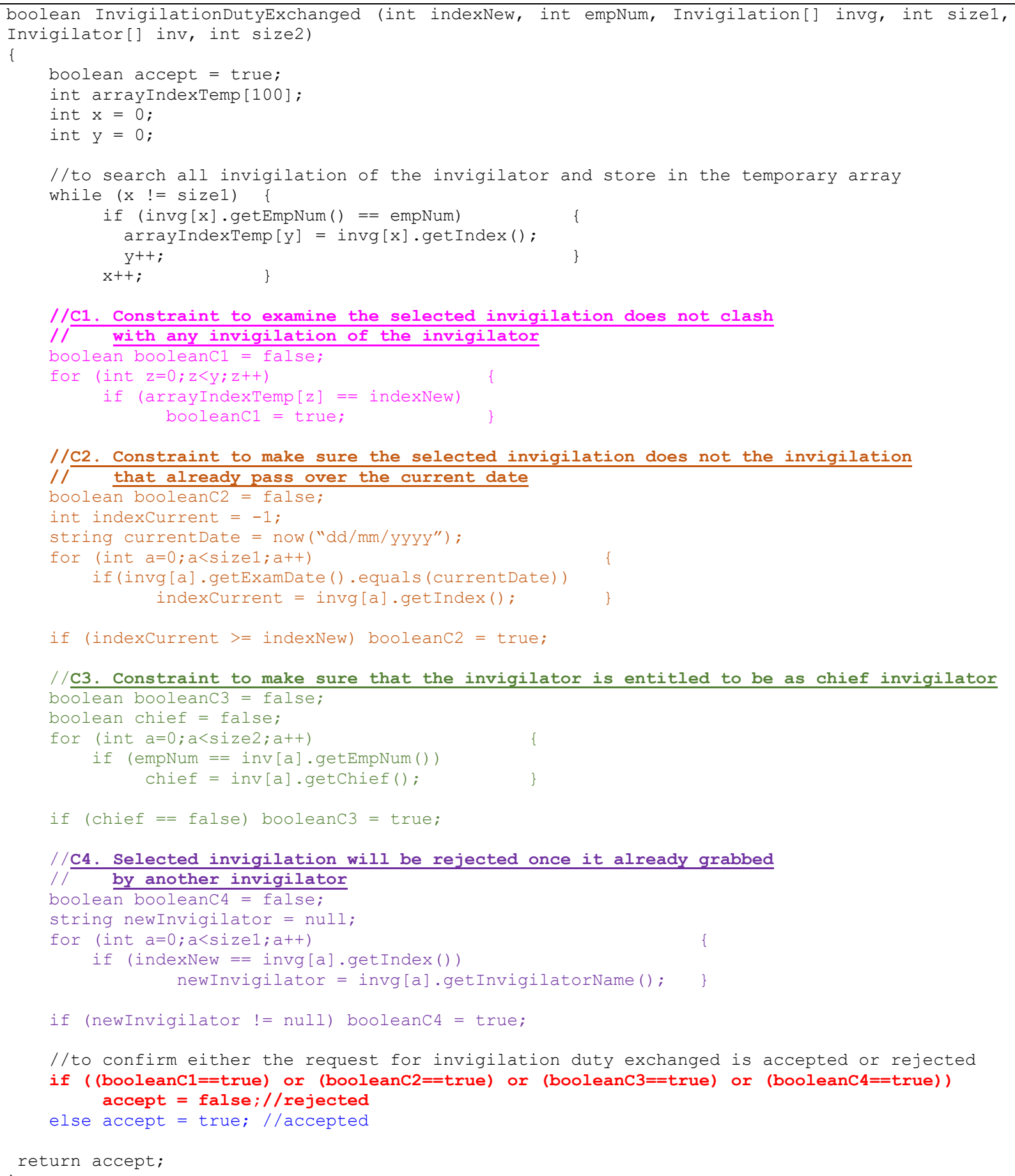

Figure 2: Algorithm of multi selection control for invigilation duty exchange

The function or subroutine as shown in the Figure 2 will return the boolean result whereby if any of the variables namely booleanc1, booleanc2, booleanc3 and booleanc4 are true, then the function will return false (representing the request is rejected); otherwise, it will return to true (representing the request is permitted). The algorithm was developed using the HTML and PHP programming languages for web-based 
or online platform. When the invigilators want to make the duty exchange with other invigilators, they need to browse the website named Examination Invigilation Management System (ExIMS). Through the web page, the invigilators will select the invigilation to be released and choose any of the invigilation, provided that the selected invigilation has fulfilled the $\mathrm{C} 1, \mathrm{C} 2, \mathrm{C} 3$ and $\mathrm{C} 4$ constraints. If all the constraints are fulfilled, then the exchanged of invigilation duty will be granted by the system. The following Figure 3, 4, 5 and 6 are examples of constraints $\mathrm{C} 1, \mathrm{C} 2, \mathrm{C} 3$ and $\mathrm{C} 4$, respectively, for invigilation duty exchanged through ExIMS with the implementation of multi selection control algorithm.

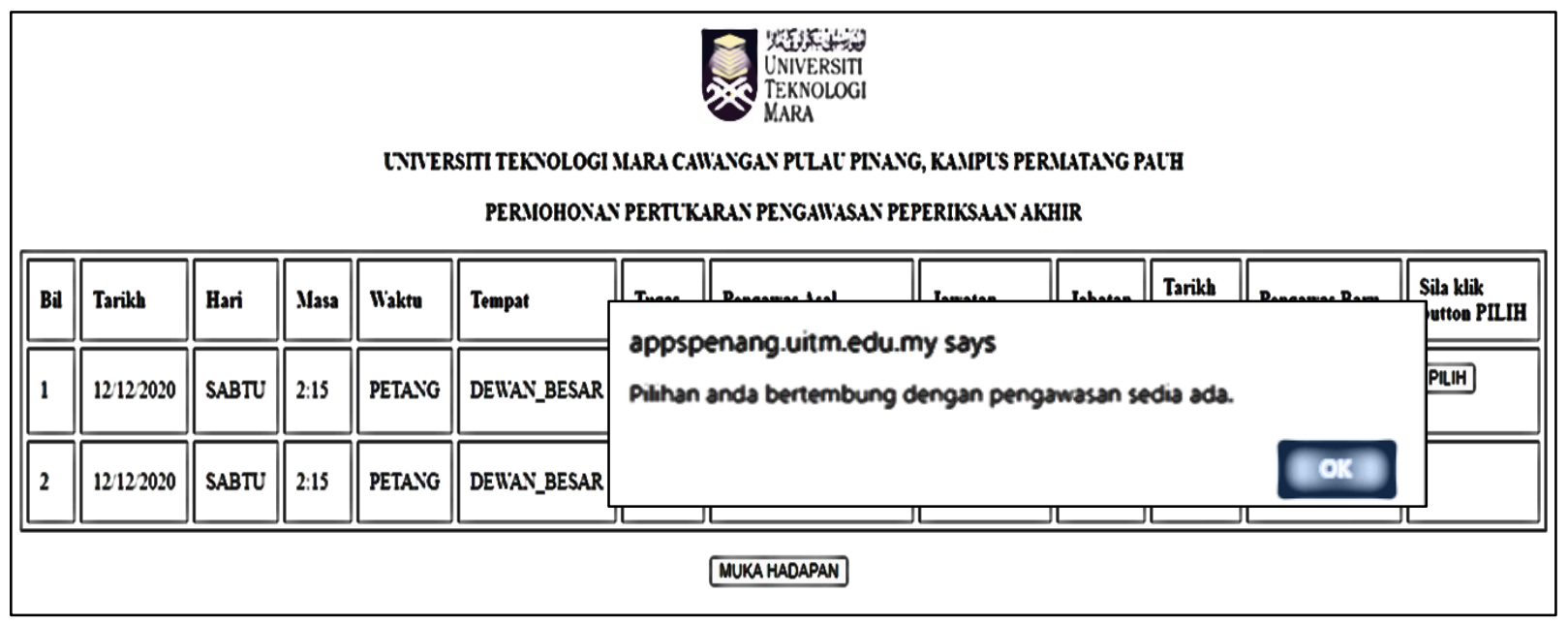

Figure 3: Example shows that the selected invigilation clashed with the existing invigilation.

This is the $\mathrm{C} 1$ controls.

\begin{tabular}{|c|c|c|c|c|c|c|c|c|c|c|c|c|}
\hline & & & & TSIE & $\begin{array}{l}\text { TTI TEKNOLOGI } \\
\text { PERMOHONA }\end{array}$ & $\begin{array}{l}\text { IARACAI } \\
\text { PERTCK }\end{array}$ & 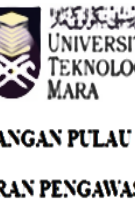 & KAMPLS & $\begin{array}{l}\text { LATANG P } \\
\text { IIR }\end{array}$ & & & \\
\hline Bil & Tarikh & Hari & Masa & Waktu & Tempat & Tugas & Pengawas Asal & Jawatan & Jabatan & $\begin{array}{l}\text { Tarikh } \\
\text { Mohou }\end{array}$ & Pengawas Baru & $\begin{array}{l}\text { Sila klik } \\
\text { button PIIIH }\end{array}$ \\
\hline 1 & 12122020 & SABTU & 2:15 & PETAIG & DEWAN_BESAR & $\mathrm{PK}(\mathrm{P})$ & \multirow{3}{*}{\multicolumn{4}{|c|}{$\begin{array}{l}\text { appspenang.uitm.edu.my says } \\
\text { Mast, anda memilh tarikh pengawasan yang lepas }\end{array}$}} & & \\
\hline 2 & 12122020 & SABTU & 2:15 & PETAIOG & DEWAN_BESAR & $\mathrm{PuB}(\mathrm{P})$ & & & & & & \\
\hline 3 & $3011 / 2020$ & IS.NN & 9.00 & PAGI & DEWAN_BESAR & $\mathrm{PuB}(\mathrm{P})$ & & & & & & \\
\hline & & & & & & & NUKA HADAPAN & & & & & \\
\hline
\end{tabular}

Figure 4: Example shows that the invigilator selected the invigilation date that already passed over the current date. (assuming the current date is $5^{\text {th }}$ Dec 2020 and the invigilator chose the record number 3 ).

This is the $\mathrm{C} 2$ controls. 


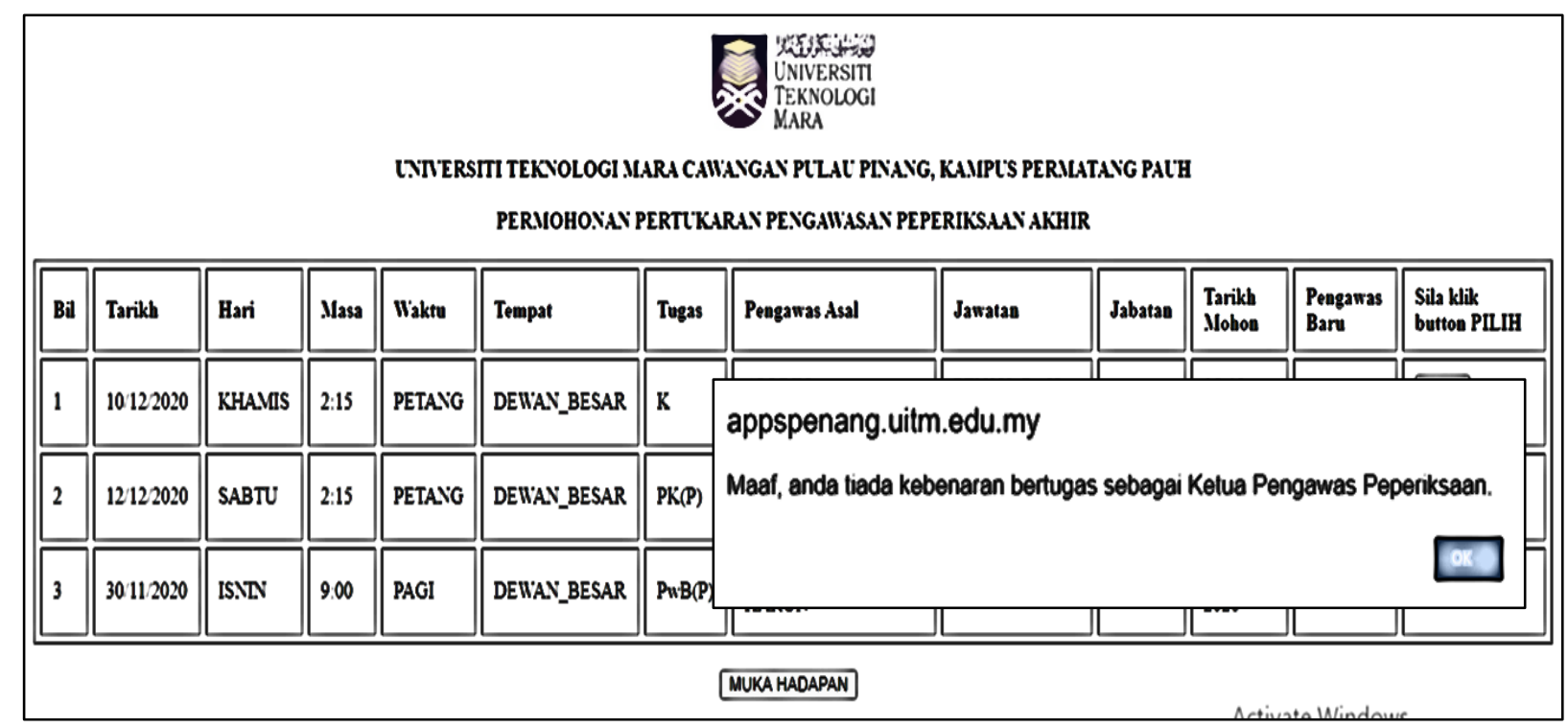

Figure 5: Example shows that the invigilator chose the invigilation with the role as a chief invigilator. (assuming the invigilator chose the record number 1)

This is the $\mathrm{C} 3$ controls.

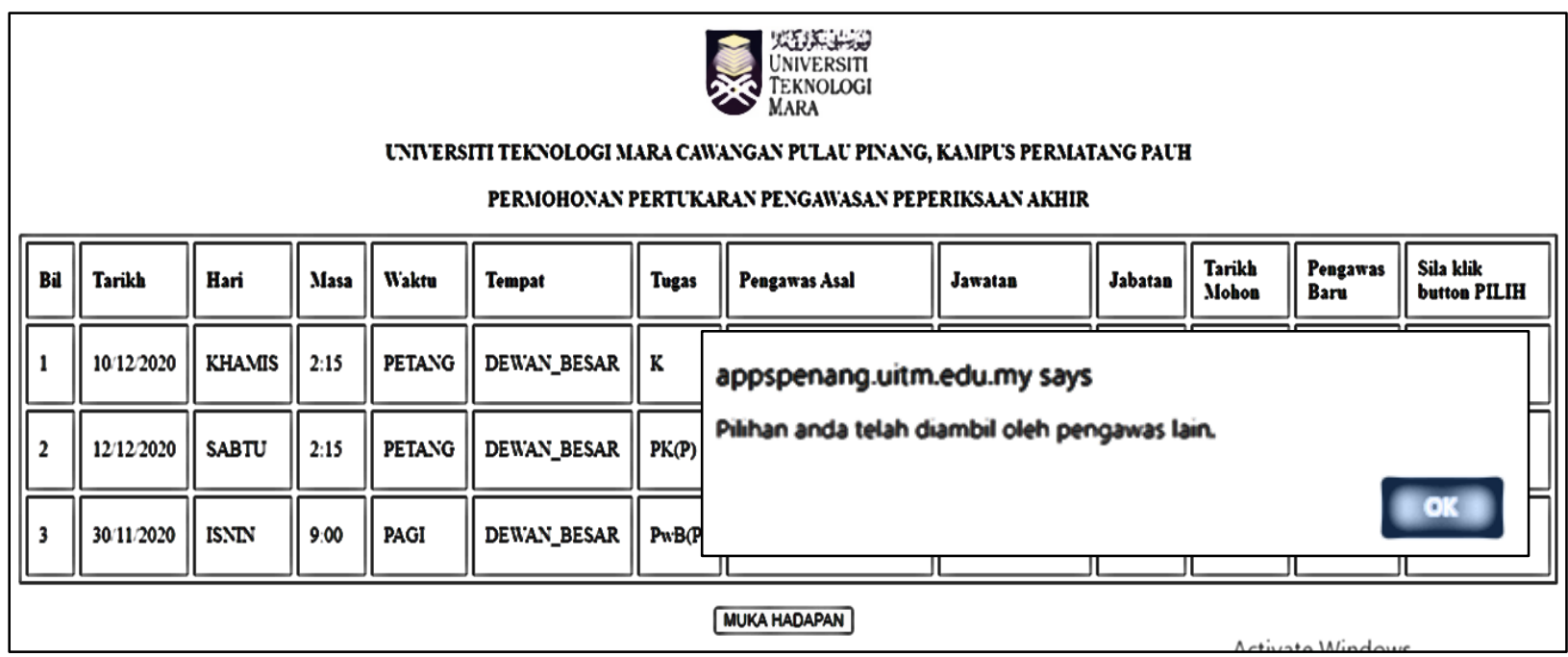

Figure 6: Example shows that the invigilator had chosen the invigilation that has been already taken by another invigilator. (assuming the invigilator chose the record number 1)

This is an example of concurrency issue whenever several users choose the same record at the same time (difference in a few milliseconds), but the system approved the request based on the first come first serve basis (FCFS).

This is the $\mathrm{C} 4$ controls.

Based on the examples shown in the figures 3, 4, 5 and 6, Examination Invigilation Management System (ExIMS) has successfully controlled an abnormality and avoid anomalies of invigilation duty exchange among invigilators so that the invigilation records in the systems are always clean and no conflicts or clashes of duty among invigilators could happen during the invigilation day. This way, examination operation can run smoothly and efficiently. 


\section{FINDINGS AND DISCUSSIONS}

To measure the users' acceptance level or satisfaction on the new system named Examination Invigilation Management System (ExIMS), which applies the Multiple Selection Controls algorithm in invigilation duty exchange, an online survey was conducted after the invigilators received their invigilation duties. The questions of the online survey were constructed based on the Technology Acceptance Model (TAM). TAM is an information systems theory that models how the users accept and use the technology (Wikipedia, 2020). For this project, the survey was focused on the perceived-ease-of-use (PEOU) in which the respondents were required to respond on the easiness of using the ExIMS for invigilation duty exchange process. Five (5) options using the Likert Scale from the scale 1 for strongly disagree until scale 5 for strongly agree were the options for each question that the users can choose. There are three (3) main factors related to the users' acceptance level or satisfaction for this system. These factors are invigilation duty, the interface of ExIMS systems and the application of invigilation duty exchange.

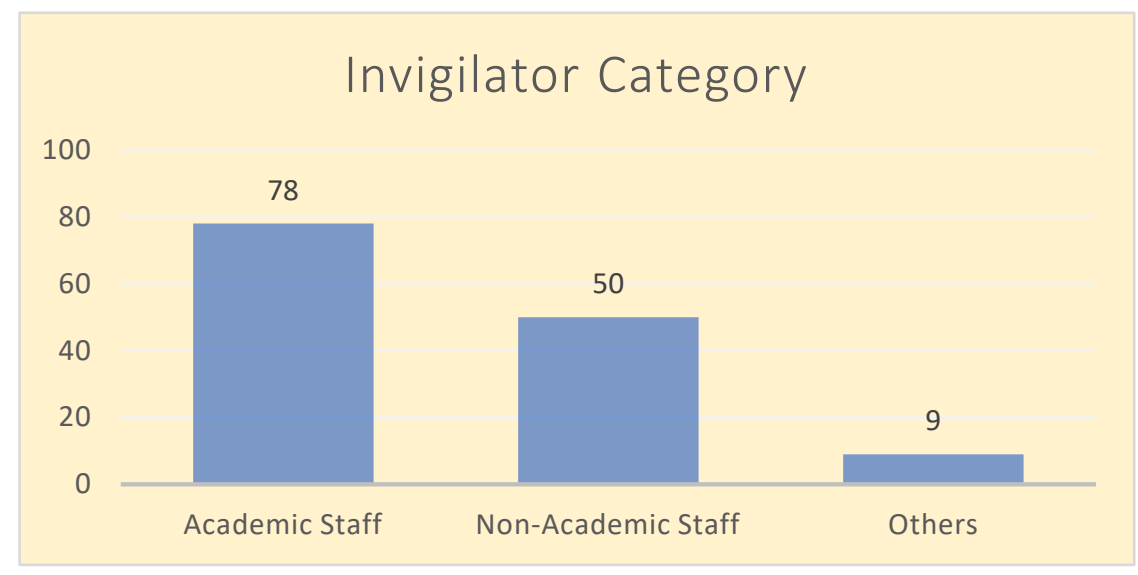

Figure 7: The Category of Invigilator

Based on Figure 7, a total of 137 respondents were obtained from the survey. There were 78 respondents consisted of academic staff, 50 respondents from non-academic staff and 9 respondents from the people hired by the university as assistant invigilators. The number of academic staff involved was higher because the ratio of lecturers in university are larger than non-academic staff.

Table 2: Descriptive statistics analysis for the users' acceptance level

\begin{tabular}{|l|r|r|r|r|r|}
\hline \multicolumn{7}{|c|}{ Descriptive Statistics } \\
\hline & $\mathrm{N}$ & Minimum & Maximum & Mean & Std. Deviation \\
\hline Level of Satisfaction & 137 & 2.33 & 5.00 & 4.4428 & .32366 \\
\hline Invigilation Duty & 137 & 1.00 & 4.00 & 2.8759 & .50286 \\
\hline System Interface & 137 & 3.00 & 5.00 & 4.4562 & .43923 \\
\hline $\begin{array}{l}\text { Application } \\
\text { Invigilation Exchange }\end{array}$ & 137 & 3.00 & 5.00 & 4.5401 & .48149 \\
\hline Valid N (listwise) & 137 & & & & \\
\hline
\end{tabular}

Table 2 shows that the maximum users' acceptance or satisfaction level for this system is 5 which is strongly agreed with this system, as well as the system interface and the application of invigilation exchange, where 
the maximum user preference is strongly agreed that the system is beneficial, whereas the minimum chosen is 3 which moderately agreed with this system. On average, users choose to agree on a system developed with a mean of 4.4. Overall, the result from the descriptive statistics analysis in Table 2 shows that the level of users' acceptance to this system was found to be positive.

Table 3: Correlation between invigilation duty and level of users' satisfaction

\begin{tabular}{|l|l|r|r|}
\hline \multicolumn{2}{|c|}{} & $\begin{array}{c}\text { Invigilation } \\
\text { Duty }\end{array}$ & $\begin{array}{c}\text { Level of } \\
\text { Satisfaction }\end{array}$ \\
\hline \multirow{3}{*}{ Invigilation Duty } & Pearson Correlation & 1 & -.089 \\
\cline { 2 - 4 } & Sig. (2-tailed) & & .301 \\
\cline { 2 - 4 } & $\mathrm{N}$ & 137 & 137 \\
\hline \multirow{2}{*}{ Level of Satisfaction } & Pearson Correlation & -.089 & 1 \\
\cline { 2 - 4 } & Sig. (2-tailed) & .301 & 137 \\
\cline { 2 - 4 } & $\mathrm{N}$ & 137 & \\
\hline
\end{tabular}

Table 3 shows that it is not significant and negligible association that existed between the level of satisfaction and invigilation duty since the Pearson Correlation was equal to -0.09 .

Table 4: Correlation between system interface and level of user satisfaction

\begin{tabular}{|l|l|r|r|}
\hline \multicolumn{2}{|c|}{} & \multicolumn{1}{|c|}{$\begin{array}{c}\text { System } \\
\text { Interface }\end{array}$} & $\begin{array}{c}\text { Level of } \\
\text { Satisfaction }\end{array}$ \\
\hline \multirow{3}{*}{ System Interface } & Pearson Correlation & 1 & .155 \\
\cline { 2 - 4 } & Sig. (2-tailed) & & .071 \\
\cline { 2 - 4 } & N & 137 & 137 \\
\hline \multirow{2}{*}{ Level of Satisfaction } & Pearson Correlation & .155 & 1 \\
\cline { 2 - 4 } & Sig. (2-tailed) & .071 & 137 \\
\cline { 2 - 4 } & N & 137 & 1 \\
\hline
\end{tabular}

Table 4 illustrates it is not significant and negligible association between the level of satisfaction and system interface since the Pearson Correlation was equal to 0.155 .

Table 5: Correlation between application of invigilation exchange and level of user satisfaction

\begin{tabular}{|l|l|r|r|}
\hline \multicolumn{2}{|l|}{} & $\begin{array}{c}\text { Application of } \\
\text { Invigilation } \\
\text { Exchange }\end{array}$ & \multicolumn{1}{c|}{$\begin{array}{c}\text { Level of } \\
\text { Satisfaction }\end{array}$} \\
\hline $\begin{array}{l}\text { Application of } \\
\text { Invigilation Exchange }\end{array}$ & Pearson Correlation & 1 & $.278^{* *}$ \\
\cline { 2 - 5 } & Sig. (2-tailed) & & .001 \\
\cline { 2 - 5 } & $\mathrm{N}$ & 137 & 137 \\
\hline Level of Satisfaction & Pearson Correlation & $.278^{* *}$ & 1 \\
\cline { 2 - 5 } & Sig. (2-tailed) & .001 & 137 \\
\cline { 2 - 5 } & $\mathrm{N}$ & 137 & \\
\hline
\end{tabular}


The output on Table 5 confirmed the existence of a significant and weak positive relationship between level of satisfaction and application of invigilation exchange since the Pearson Correlation was equal to 0.278. This indicates that respondents satisfied with the application of invigilation exchange since it is easy and practical to use compared to the manual method.

Table 6: The Significance of Coefficients

\begin{tabular}{|c|c|c|c|c|c|c|}
\hline \multirow{2}{*}{\multicolumn{2}{|c|}{ Model }} & \multicolumn{2}{|c|}{$\begin{array}{c}\text { Unstandardised } \\
\text { Coefficients }\end{array}$} & \multirow{3}{*}{$\begin{array}{c}\text { Standardised } \\
\text { Coefficients }\end{array}$} & \multirow[t]{2}{*}{$\mathrm{t}$} & \multirow[t]{2}{*}{ Sig. } \\
\hline & & B & $\begin{array}{l}\text { Std. } \\
\text { Error }\end{array}$ & & & \\
\hline \multirow[t]{4}{*}{1} & (Constant) & 3.301 & .390 & & 8.470 & .000 \\
\hline & Invigilation Duty & -.062 & .053 & -.096 & $\begin{array}{r}- \\
1.172 \\
\end{array}$ & .243 \\
\hline & System Interface & .108 & .060 & .146 & 1.781 & .077 \\
\hline & $\begin{array}{l}\text { Application of } \\
\text { Invigilation Exchange }\end{array}$ & .185 & .055 & .275 & 3.358 & .001 \\
\hline
\end{tabular}

Based on Table 6, the variable of the application for invigilation exchange only can be entered into the regression equation. This was because the significant $t$-value was equal to $0.001(\mathrm{p}<0.05)$. However, another two independent variables namely invigilation duty and system interface failed to meet the selection criteria as indicated by the non-significant $t$-values $(0.243$ and 0.077$)$ with $p>0.05$. The regression equation indicates that ExIMS system helped the examination operation to run smoothly and efficiently.

\section{CONCLUSION AND RECOMMENDATIONS}

The implementation of Examination Invigilation Management Systems (ExIMS) has improved the level of user satisfaction since it helps users to make the application of the invigilation exchange easily. In addition, based on the overall feedback given through the online survey and verbal interview, can be concluded that 99\% of invigilators were comfortable and satisfied with the system. System enhancement of ExIMS still continues and progresses. The algorithm of Multiple Selection Control is modifiable to strengthen the structure of algorithm. Additional two constraints have been initiated by the respondents through the online survey as listed in the Table 7 to be embedded in the existing algorithm.

Table 7: List of new constraints

\begin{tabular}{l|l|l}
$\begin{array}{l}\text { Constraint } \\
\text { number }\end{array}$ & Constraint or condition description \\
\hline C5* & To avoid the invigilator from invigilating the same subject as taught by him. \\
\hline C6* & $\begin{array}{l}\text { To control the Muslim male invigilators who are not invigilating during the } \\
\text { Friday afternoon slot. }\end{array}$ \\
\hline & *new constraints
\end{tabular}

More soft constraints will be introduced and embedded in the algorithm if feasible and acceptable. Among the limitation of the system development is to prioritize the constraints. For any project of system development, the system developer will concentrate on the higher priority of system constraints. The developer will improve the system features by slowly embedding new constraints for system improvisation 
but still depends on the algorithm efficiency. This project has categorized the hard and soft constraints, so that the system development process runs according to the schedule. Nevertheless, not all soft constraints will be embedded in the system if the algorithm performance suddenly become inefficient.

Improvisation of algorithm will produce better comprehensive algorithm, which caters all types of controls and constraints at optimum requirements and consequently, the invigilation integrity of the institution will be recognisable and respectful.

\section{ACKNOWLEDGMENTS}

The authors would like to acknowledge the Rector and Deputy Rector of Academic Affairs for giving the permission and opportunity to implement the Examination Invigilation Management System (ExIMS) at UiTM Pulau Pinang branch. Not to forget all invigilators who were very supportive in sharing valuable ideas for system enhancement and improvement.

\section{REFERENCES}

Ahmed, A., Sajid, A., Ali, M., \& Bukhari, A. H. S. (2011). Particle Swarm Optimization Based HyperHeuristic For Tackling Real World Examinations Scheduling Problem. Australian Journal of Basic and Applied Sciences, 5, 1406-1413.

Avinash, B.R., Vijaykumar, D.V., Rajeev, M.P., Parkar, V. V. (2015) “Automated Examination Support System". International Journal of Current Engineering and Technology, Vol 5, Number 1, February 2015, E-ISSN 2277 - 4106, P-ISSN 2347 - 5161.

Carter, M. W., \& Laporte, G. (1997). Recent developments in practical course timetabling. In International Conference on the Practice and Theory of Automated Timetabling (pp. 3-19). Springer.

Dharshini, S.P., Sudha, M.S. (2018). "Exam Cell Automation System," International Journal of Engineering Science and Computing (IJESC), Vol 7, Number 3.

Di Gaspero, L., Schaerf, A., Cadoli, M., Slany, W., \& Falaschi, M. (2003). Local Search Techniques for Scheduling Problems: Algorithms and Software Tool. Forum.

Existek. (2020). “SDLC Models Guide”, Retrieved December 04, 2020, from https://existek.com/blog/sdlcmodels/

Sagir, M., \& Ozturk, Z. K. (2010). Exam scheduling: Mathematical modeling and parameter estimation with the Analytic Network Process approach. Mathematical and Computer Modelling, 52(5), 930-941.

HEA. (2019). "Minute Meeting of Examination Committee", Department of Academic Affairs, UiTM Cawangan Pulau Pinang, Number 2/2019.

Kahar, M. N. M., \& Kendall, G. (2010). The examination timetabling problem at Universiti Malaysia Pahang: Comparison of a constructive heuristic with an existing software solution. European Journal of Operational Research, 207(2), 557-565.

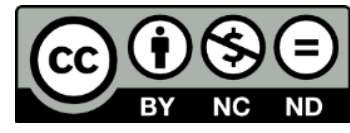

Copyright $\odot 2021$ UiTM Press. This is an open access article under the CC BY-NC-ND (https://creativecommons.org/licenses/by-nc-nd/4.0/) 
Mat Yusof, K. (2020), "Invigilator System for UMP Examination Problem Based on Faculty of Computer System \& Software Engineering (FSKKP)", Retrieved December 01, 2020, from DOI/Official URL: http://iportal.ump.edu.my/lib/item?id=chamo:92281\&theme=UMP2

Mohamed, A. S., Mushi, A. R., \& Mujuni, E. (2013). An Examination Scheduling Algorithm Using Graph Coloring-the case of Sokoine University of Agriculture.

Othman, J., Abdul Wahab, N., Kadar, R., Warris, S.N. (2017). Assigning Examination Invigilator's Schedule Problem: An Approach of Programming Techniques Using Simple Sequential Assignment. Journal of Computing Research \& Innovation (JCRINN) Vol 2, Number 1, pp 1-13.

Othman, J., Kadar, R., Abdul Wahab, N., Warris, S.N. (2018). Examination Management Systems: A Survey of User Acceptance Level in UiTM Cawangan Pulau Pinang. Journal of Computing Research \& Innovation (JCRINN) Vol 3, Number 1, pp 46-54.

Quality. (2010). Quality Manual of UiTM Cawangan Pulau Pinang, ISO 9001:2008.

Sarin, S. C., Wang, Y., \& Varadarajan, A. (2010). A university-timetabling problem and its solution using Benders' partitioning - a case study. Journal of Scheduling, 13(2), 131-141.

UiTM (2001), Nilai dan Etika Pensyarah, Universiti Teknologi MARA.

UiTM. (2016). Examination Procedures Manual, Academic Assessment Division of UiTM.

Wikipedia (2020). "Technology acceptance model (TAM)", Retrieved December 05, 2020 from https://en.wikipedia.org/wiki/Technology_acceptance_model

Winston, W., R. (1970). Managing the Development of Large Software Systems, Proceedings, IEEE WESCON, August 1970, pages 1-9.

Wyer, M., Eisenbach, S. (2001). "Lexis Exam Invigilation System”, Retrieved December 01, 2020 from https://www.usenix.org/legacy/publications/library/proceedings/lisa2001/tech/full papers/wyer/wyer html/index.html 